تأثير اسيد هيوميك بر شاخصهاى رشد و عملكرد آَتابخر دان (Helianthus annuus) در شرايط تنش شورى

محمودرضا تدين "، على تدين ' و سميه اسماعيلى"

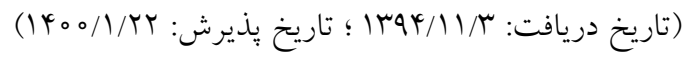

جكيده

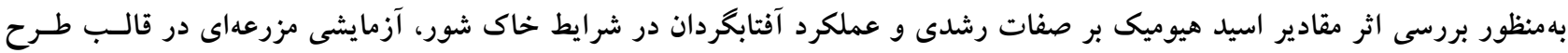

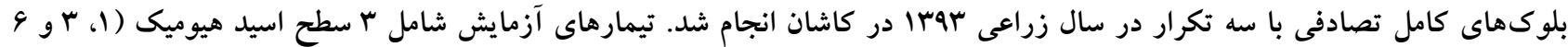

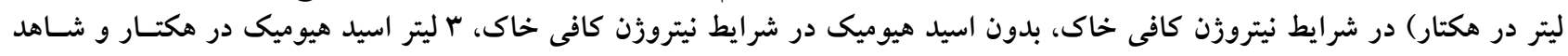

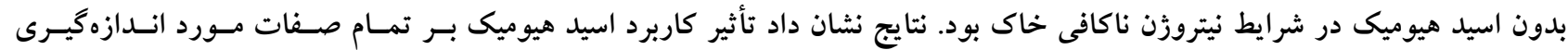

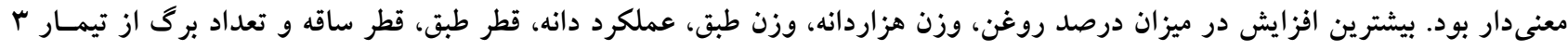

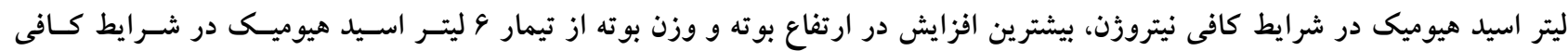

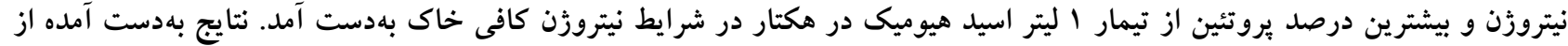

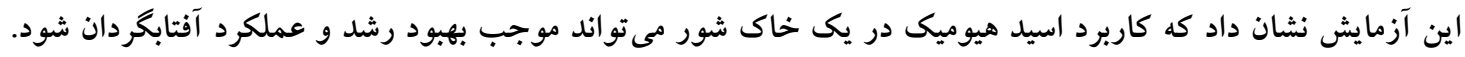

وازههاى كليدى: دانه روغنى، هدايت الكتريكى (EC) ، نيتروزن خاك، مواد هورمونى، خاك شور

ا، ז و r. بهترتيب استاد، دانشيار و دانشجوى كارشناسى ارشد كروه زراعت و اصلاح نباتات دانشكده كثاورزى دانشكاه شهركرد، شهركرد.

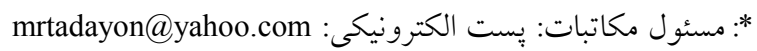


آلى خاك را تسهيل مى كند. برخى از فوايد اصلاح خاك با مـواد

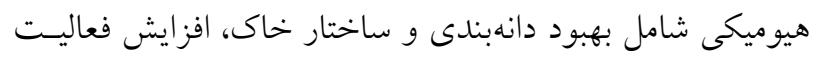

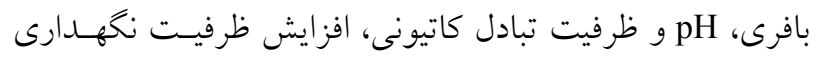

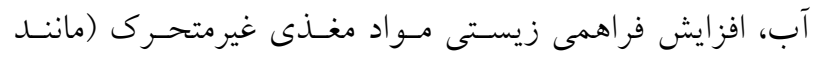

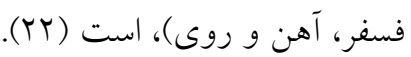

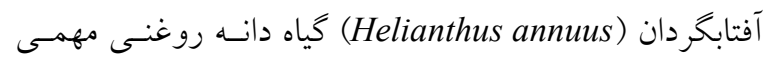
است كه در بسيارى از كشورها بيشتر براى توليــ روغـن و نيـز

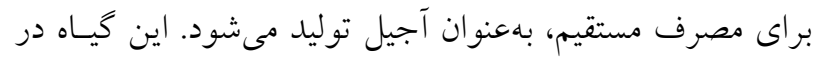

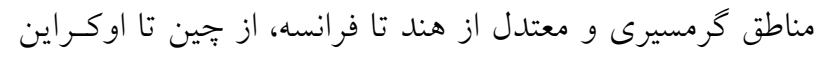

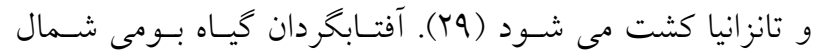

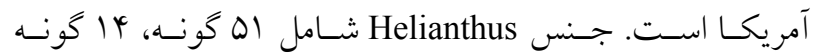

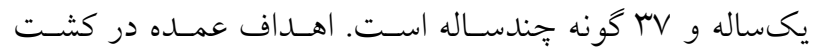
آفتابخردان، افزايش عملكرد دانـه و روغـن بـالا، بهبـود كيفيـت روغن و همجينين مقاومت در برابـر تسنشهـاى متفـاوت اسـت.

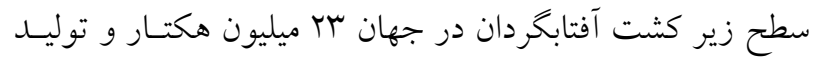

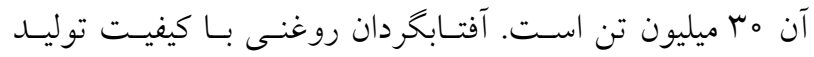

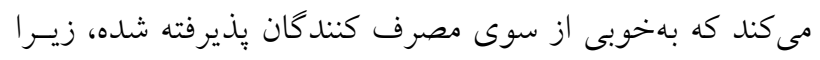

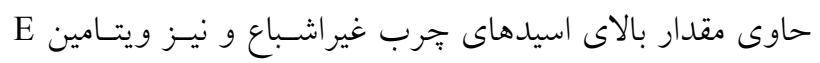

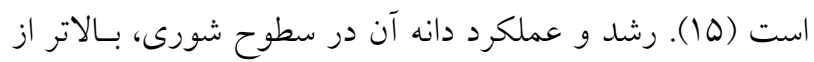

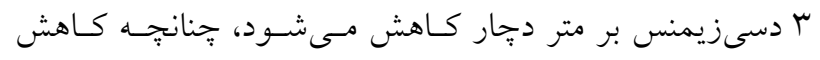

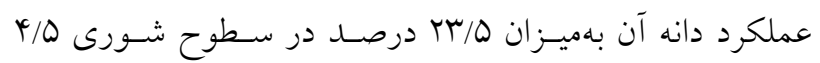
دسىزيمنس بر متر كزارش شده است (19). با اين حال كاترينـا

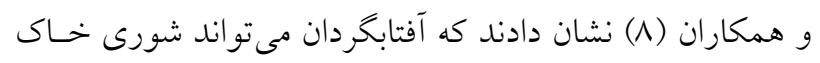

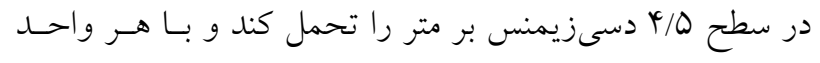

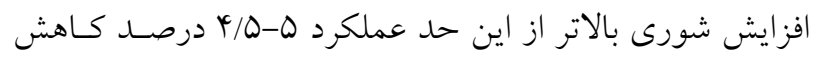
مى يابد.

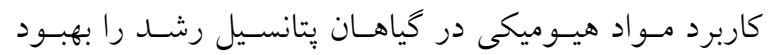
مىبخشد اما ميزان افـزايش رشـــ در كياهـان مختلـف يكسـان

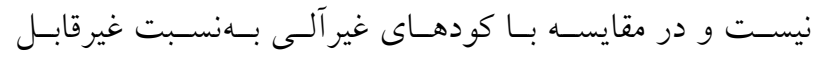

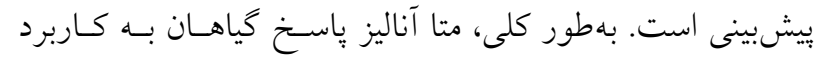

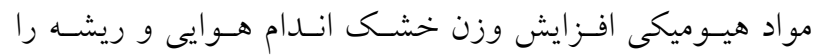

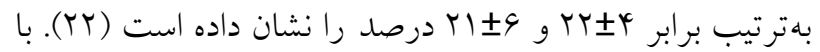

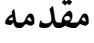

شورى خاك تهليــى جـــى در كشـاورزى در سراسـر جهان

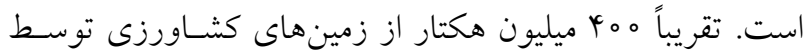

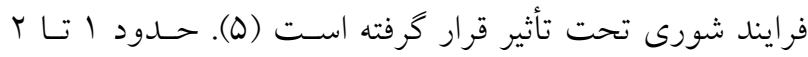

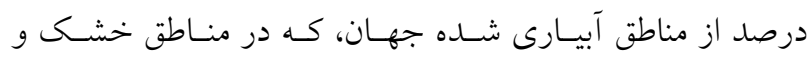

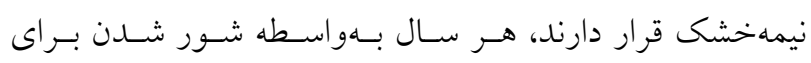

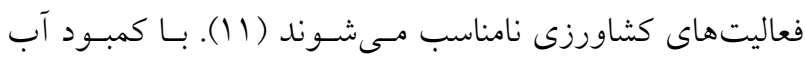

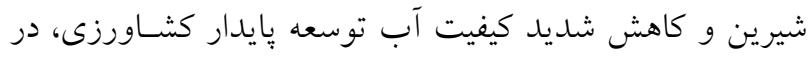

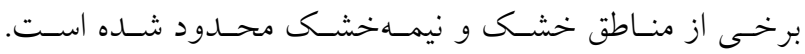

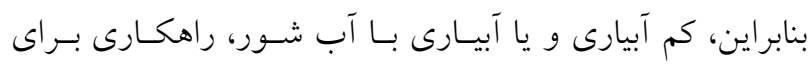

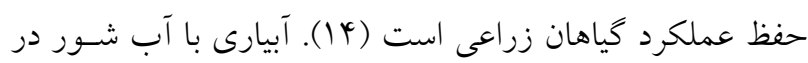

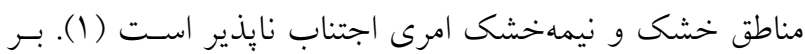

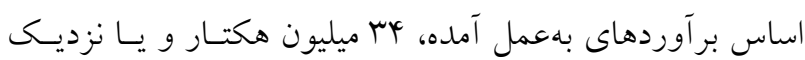
به هب درصد از مساحت كشور شور است. ه/ه ميليون هكتـار از زمينهاى زراعى داراى شورى متوسط تـا كـم و N/ه ميليـون

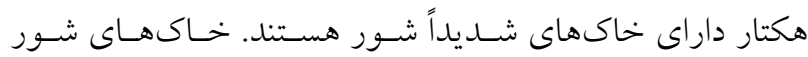
بهطور عمده در فلات مركزى، جلكههاى ساحلى جنوب، دشت

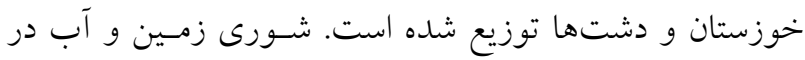
نتيجة رخدادهاى طبيعى و فعاليتهاى انسانى بوده است (Y (I).

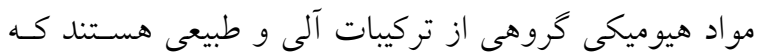

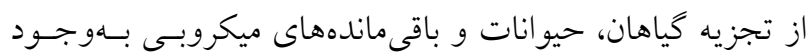

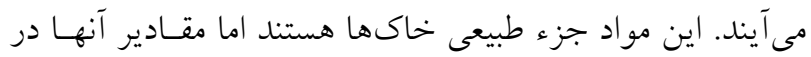

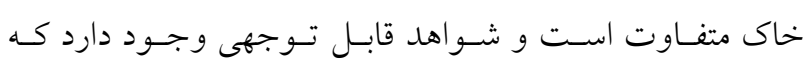

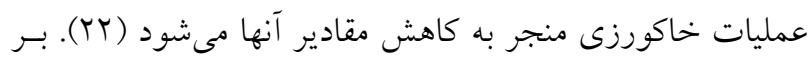

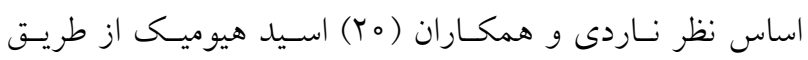

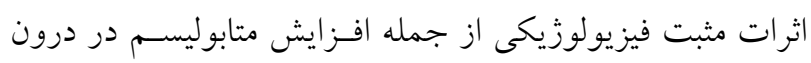

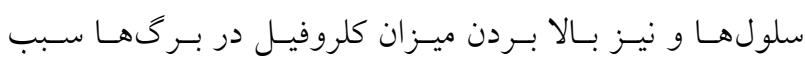

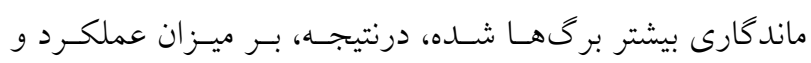

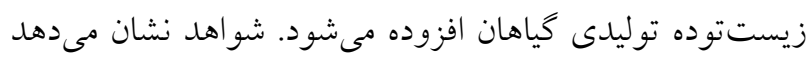

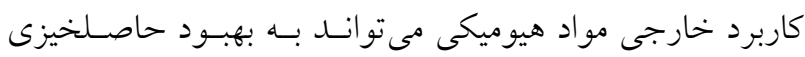

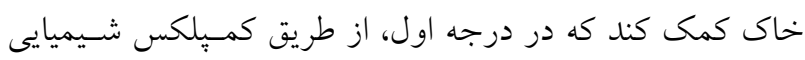

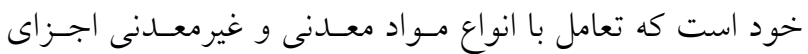


ץ ا ادرصد اسيد هيوميك بود كه با توجه به راهنماى مصـرف در

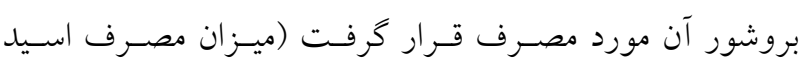

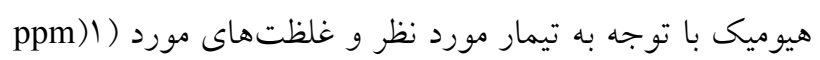

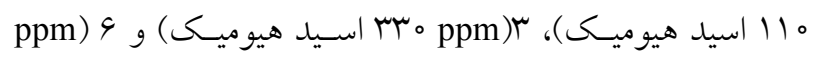

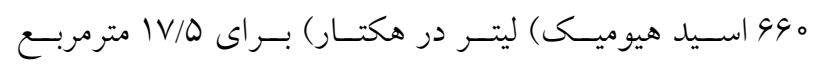

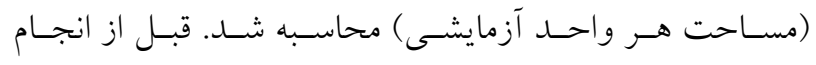

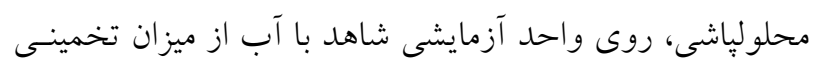

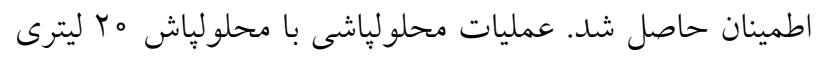

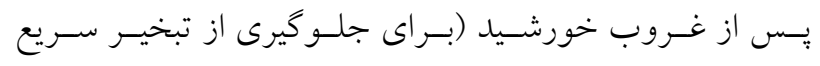

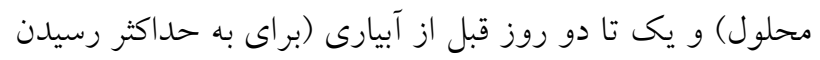

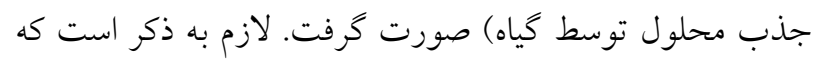
محلول مخصوص هر كرت فقط با يكبار اسيرى روى هر كرت

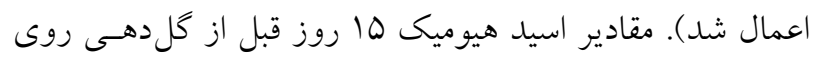

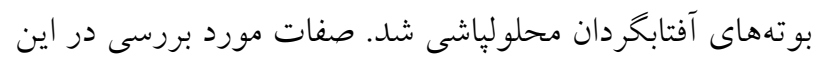

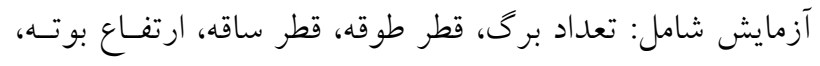

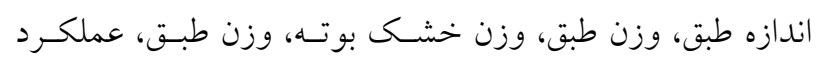

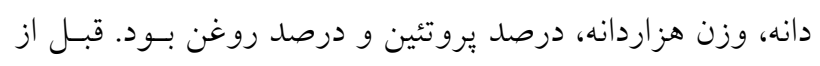

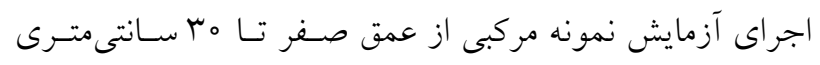

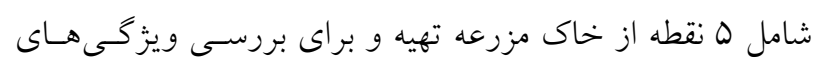

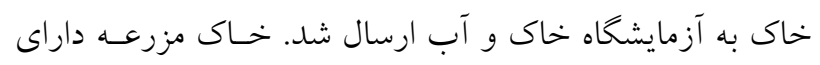

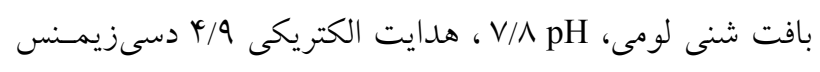

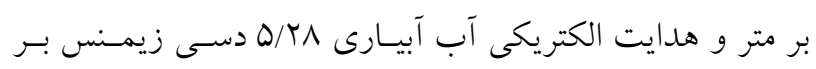

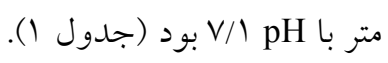

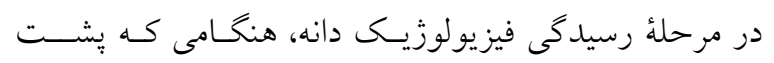

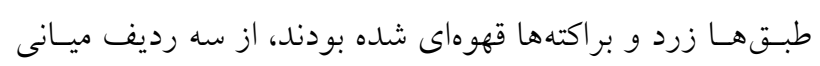

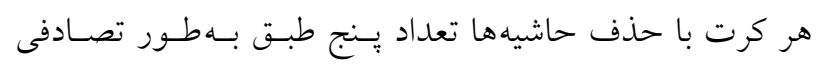

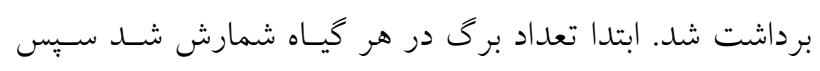

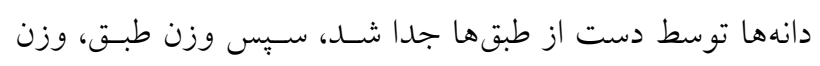

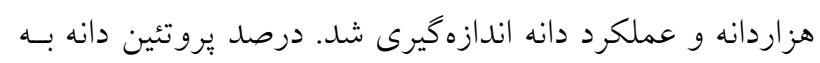

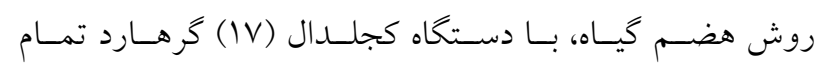

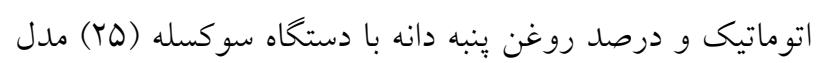

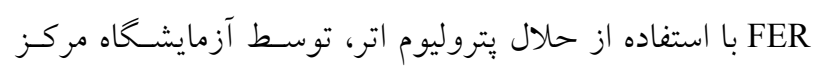

توجه به اينكه بهبود عملكرد و كيفيت روغن آفتـابكردان تحـت

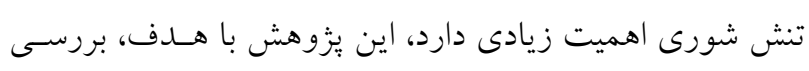

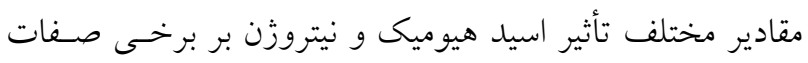

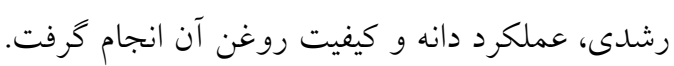

\section{مواد و روشها - ماد}

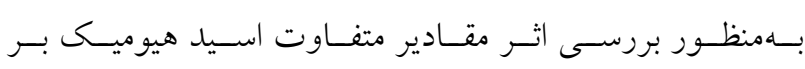

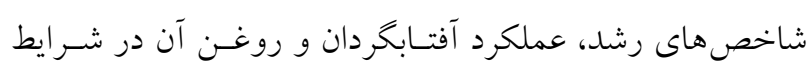

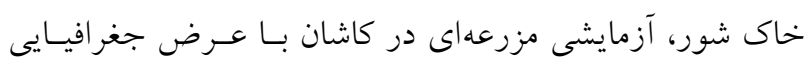

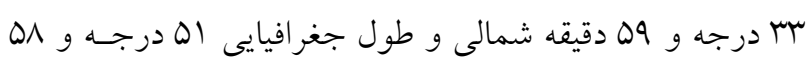

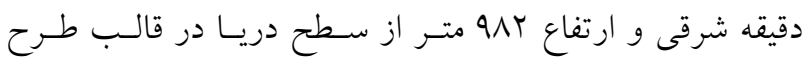

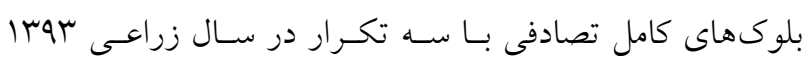

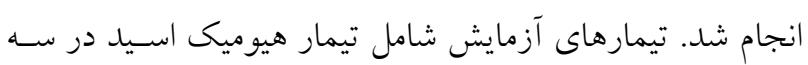

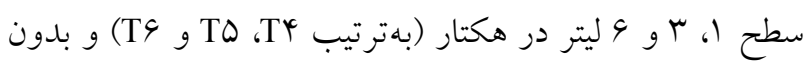

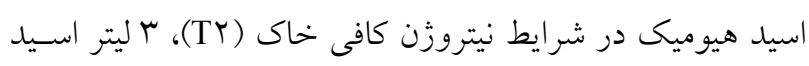

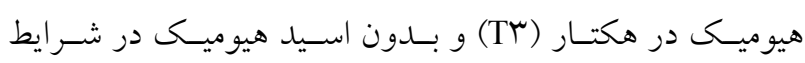

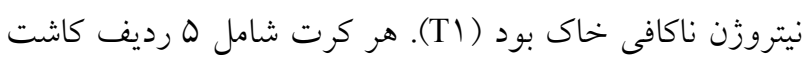

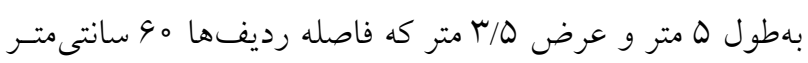

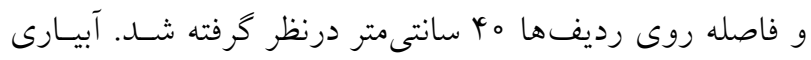

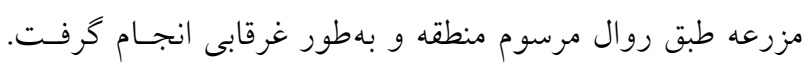

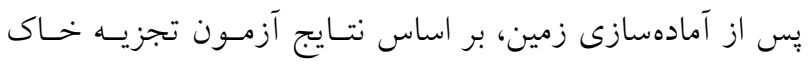

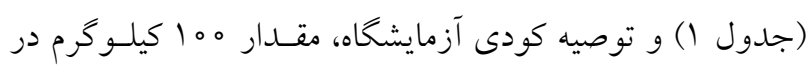

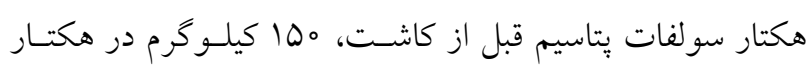

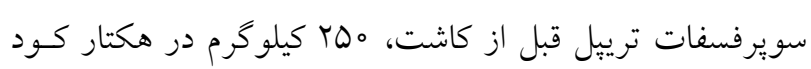

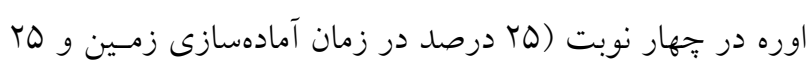

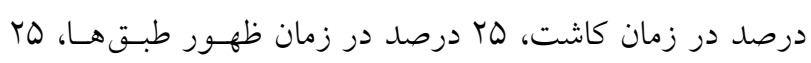

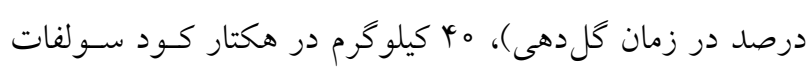

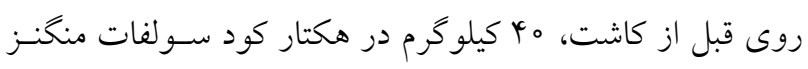

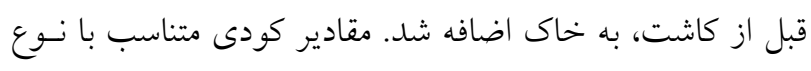

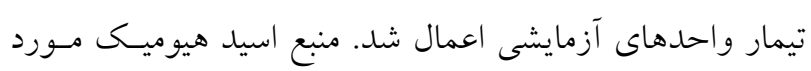

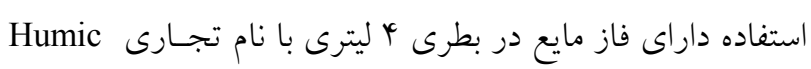
Acid 
جدول ا. خصوصيات فيزيكى و شيميايى خاك محل آزمايش در عمق صفر تا بr سانتىمترى

\begin{tabular}{|c|c|c|c|c|c|c|c|c|c|c|c|}
\hline $\mathrm{SP}$ & $\mathrm{EC}$ & $\mathrm{pH}$ & T.N.V & O.C & $\mathrm{N}$ & $\mathrm{K}$ & $\mathrm{P}$ & $\mathrm{S}$ & $\mathrm{Si}$ & $\mathrm{C}$ & \multirow{2}{*}{ بافت } \\
\hline$(\%)$ & $(\mathrm{dS} / \mathrm{m})$ & - & & $(\%)$ & & & & & (\%) & & \\
\hline$T V / Q D$ & $4 / q 1$ & $V / q$ & YI & $0 / 4 q$ & $\% 00$ & $M T Y / 4$ & $10 / 0$ & $v^{\mu}$ & ir & 14 & S.L \\
\hline
\end{tabular}

(جدول Y). با مصرف اسيد هيوميـك در شـرايط نيتـروزن كـافى صفات قطر ساقه، تعداد برى، وزن بوته و قطر طبق بهبـود يافتنـــ

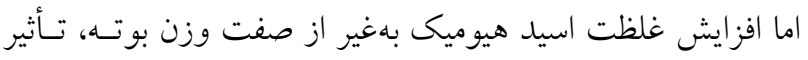

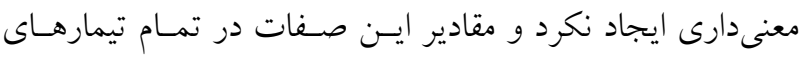

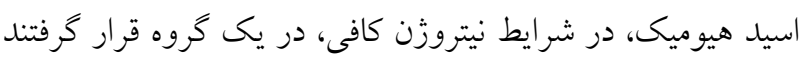

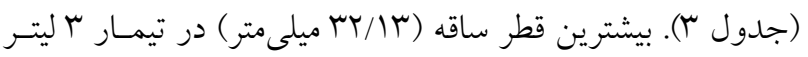

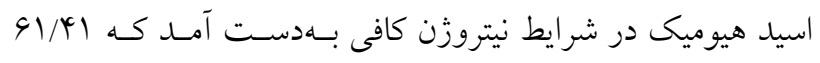

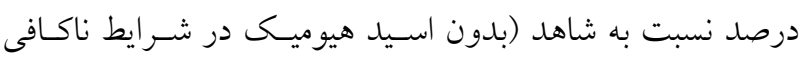

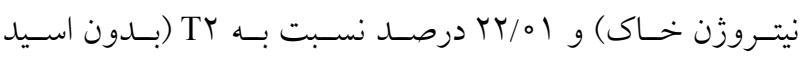
هيوميك در شرايط نيتروزن كافى خاك) افزايش داشته است.

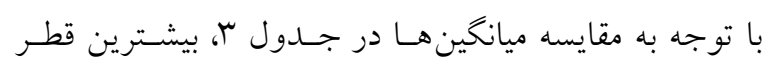

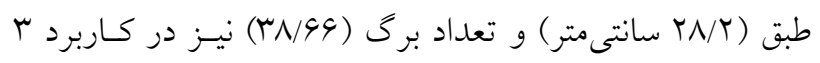

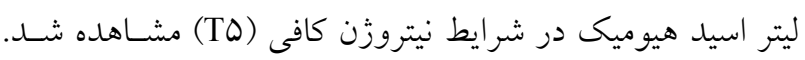

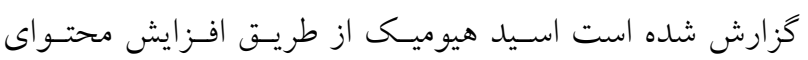

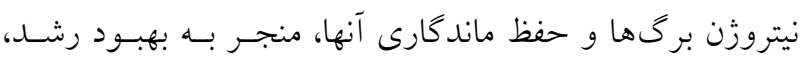

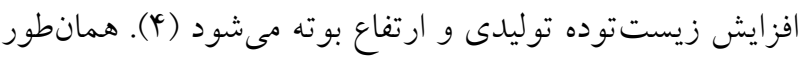

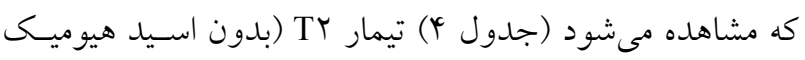

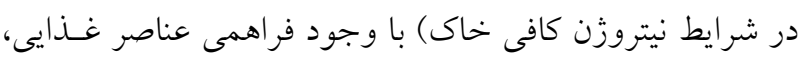

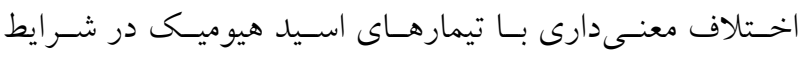

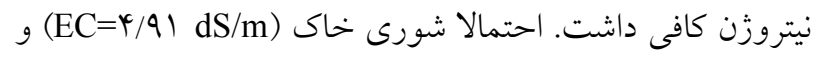

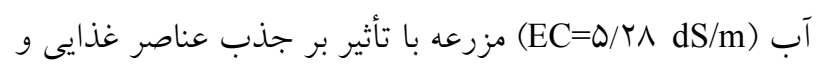

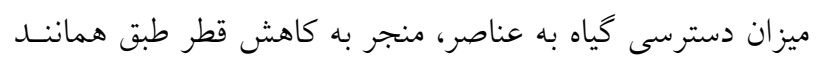
وزن دانه در طبق و وزن طبـق شــه اسـت. نـوبرز و همكـاران

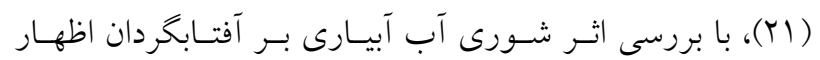

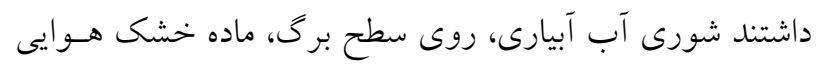

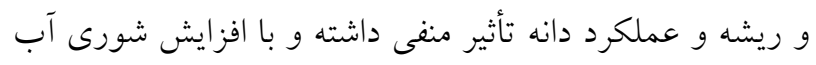

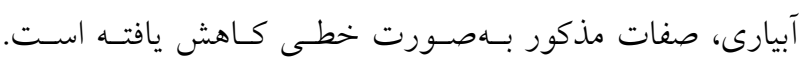

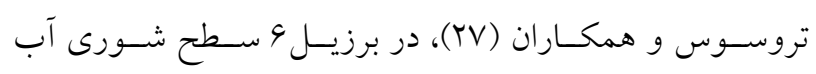

تحقيقات كشاورزى و منابع طبيعى شهركرد اندازهيــى شــند.

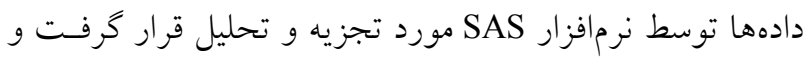
ميانخين صفات بـر اسـاس آزمـون حـــاقل معنس دارى (LSD)

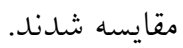

\section{نتايج و بحث}

اثر اسيد هيوميـى بـر ارتفـاع بوتـه معنسى دار شـــ (جــدول Y).

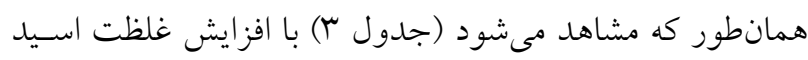

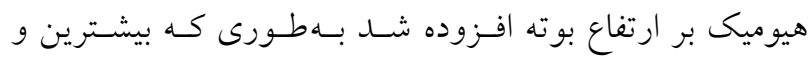

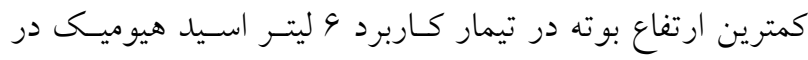

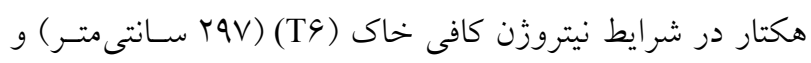

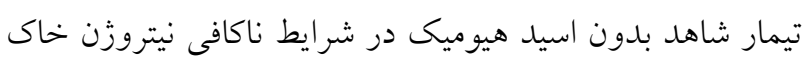
(10V) (TI)

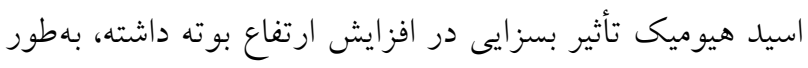

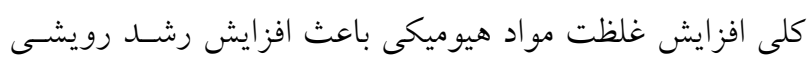

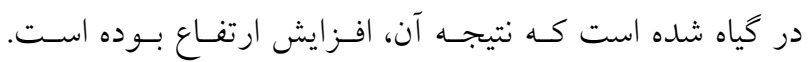

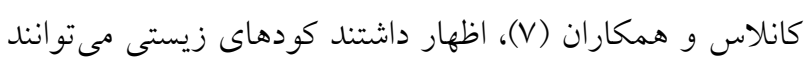

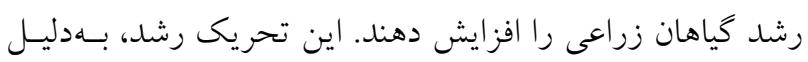

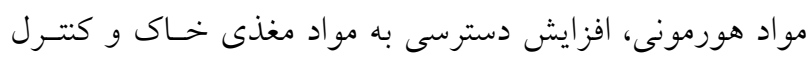

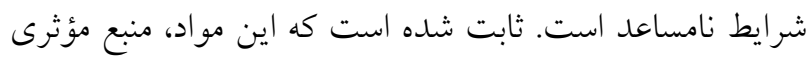
از نيتروزن هستند كه تا حدى مى توانند جايكزين كود نيتروزنسه

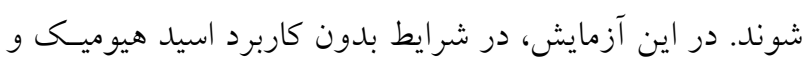

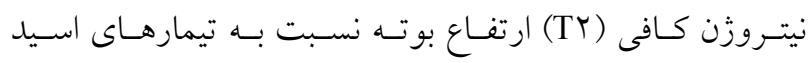

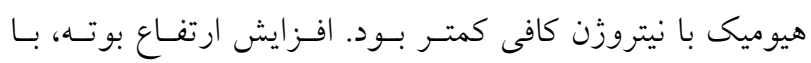

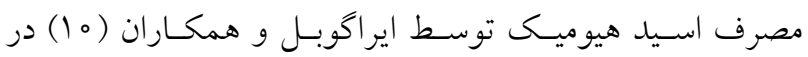
ذرت نيز كزارش شد.

كاربرد سطوح مختلف اسيد هيوميك باعث افزرايش معنسىدار

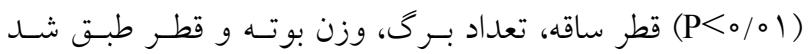


مقاله علمى - بروهشى: تأثير اسيد هيوميك بر شاخصهاى رشد و عملكرد....

جدول r. نتايج آناليز واريانس (ميانخين مربعات) صفات اندازهگيرى شده آفتابخردان در سطوح مختلف اسيد هيوميك

\begin{tabular}{|c|c|c|c|c|c|c|c|c|}
\hline عملكرد دانه & وزن طبق & قطر طبت & 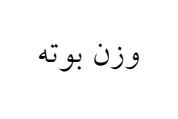 & تعداد برگ & قطر ساقه & ارتفاع بوته & درجهي & منابع تغييرات \\
\hline VTVYN/VG & $V Q / \wedge Q$ & $D / A T$ & $11 T / T \Delta$ & $44 / 99$ & rV/or & k4s & r & تكرار \\
\hline 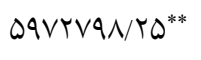 & $r \circ \notin \mu / K^{* * *}$ & $r Y / \Delta Q^{* *}$ & rorvq/৭^** & $\Delta \Delta / \Psi^{*} \mu^{* *}$ & $1 \wedge r / 9 V^{* *}$ & $V T \vee q / \Psi \varphi^{* *}$ & 0 & اسيد هيوميك \\
\hline $110 \mu \circ 9 / 01$ & $V 4 / 0 q$ & r & $010 / \mu^{4}$ & $10 / 10$ & $10 / T \Lambda$ & TYQ/KG & 10 & خطا \\
\hline $10 / 49$ & $1 r / \circ 9$ & $V / \pi I$ & $9 / 91$ & $9 / 90$ & ir & $\mathrm{V} / \circ \mathrm{Q}$ & & درصد تغييرات (\%) \\
\hline
\end{tabular}

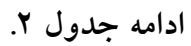

\begin{tabular}{|c|c|c|c|c|c|}
\hline شاخص برداشت & درصد يروتئين & درصد روغن & وزن هزاردانه & درجه آزادى & منابع تغييرات \\
\hline$\Delta / \Delta \wedge$ & $\circ / \wedge \wedge$ & $\circ / V Y$ & $\Delta r / \Delta \Delta$ & r & تكرار \\
\hline $09 / 90^{*}$ & $1 / 11^{*}$ & $r / 99^{* *}$ & $r \circ 9 r / 10^{* *}$ & 0 & اسيد هيوميك \\
\hline r & $\circ / T V$ & O/Y & 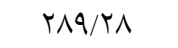 & 10 & خطا \\
\hline$V / 09$ & $T / \Psi V$ & $1 / 0 Y$ & $10 / 01$ & & درصد تغييرات (\%) \\
\hline
\end{tabular}

جدول r. مقايسه ميانگين وزن بوته، ارتفاع ساقه، قطر ساقه، تعداد برگ و قطر طبق در تيمارهاى مختلف

\begin{tabular}{|c|c|c|c|c|c|c|}
\hline شاخص برداشت & $\begin{array}{c}\text { قطر طبق } \\
\text { (cm) }\end{array}$ & وزن ونه & تعداد برگ & قطر ساقه & ارتفاع ساقه & تيمارها \\
\hline$r N / \Delta T^{a}$ & $r_{0} / \xi^{\mu c d}$ & $\Lambda r / \varphi_{0} d$ & $r V / \mu^{\prime}$ & $\mid r / 4 d$ & $10 V^{d}$ & $\mathrm{~T}_{1}$ \\
\hline$r \circ / 99^{\circ}$ & $r \mu / \Delta^{b c}$ & $r \mu_{0} / T_{\circ} c$ & Tr/Trbc & $r \Delta / \circ \&^{b}$ & cسח & $\mathrm{T}_{Y}$ \\
\hline$r \mu / N I^{b c}$ & $19 / r 9 \mathrm{~d}$ & $q 4 / \pi{ }^{d}$ & $r q / \mu \mu^{c}$ & $\mid \Lambda / T G \mathrm{c}$ & $1 \wedge r / 99^{d}$ & $\mathrm{~T}_{r}$ \\
\hline$Y Y / \Lambda Y^{\mathrm{bc}}$ & $r \Delta / \mu T^{b}$ & $r 99 / T I^{b c}$ & racab & $r q / / r^{a b}$ & $Y Y D / 9 \varphi^{b}$ & $\mathrm{~T}_{4}$ \\
\hline$r \Delta / \uparrow^{4}$ ab & $r \Lambda / Y^{\mathrm{a}}$ & $r \wedge \Delta / V Y^{b}$ & MN/9qa & & rrd & $\mathrm{T}_{0}$ \\
\hline $10 / r^{d}$ & $r \Delta / Y^{b}$ & $Y \circ V / r r^{a}$ & ro/ruab & $\Gamma_{\circ / \Lambda c^{a b}}$ & rqVa & $\mathrm{T}_{4}$ \\
\hline
\end{tabular}

ميانخينهاى داراى حداقل يك حرف مشترى در هر ستون در هر تيمار، تفاوت معنىدارى در سطح احتمال ينج درصد ندارند (LSD).

اسيد هيوميك در هكتار در شرايط نيتروزن كافى خاك) بهدسـت آمــ (جدول س)، بهطورى كه نسبت به تيمار Tr (بدون اسـيد هيوميـك در شرايط نيتروزن كافى خاك) FT/FV درصد افز ايش نشـان داد. احتمـالاً كاربرد اسيد هيوميـى در غلظـت بـالا موجـب تعـديل اثـرات تـنش شورى در كياه آفتابخردان و قابليـت دسترسى بهتـر گيـاه بـه عناصـر

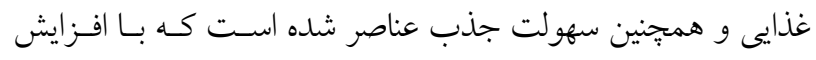

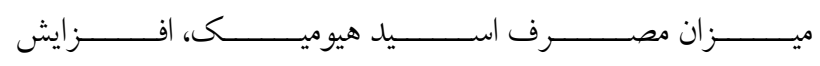

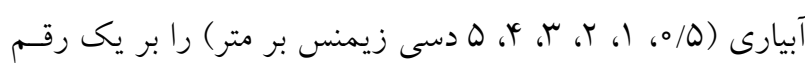

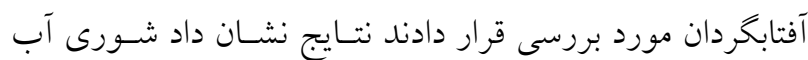

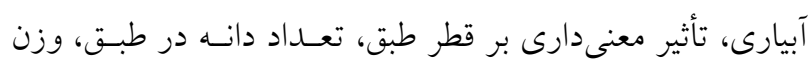
هـانه و وانه وزن كل دانه داشت بهطـورى كـه وزن كـل دانـه و تعداد دانه بهازاى افزايش هر واحد شورى آب آبيـارى وسم/11 و و (9/94 درصد كاهش يافته است.

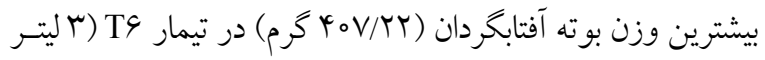


جدول f. مقايسه ميانخين وزن طبق، وزن هزاردانه، عملكرد دانه، درصد روغن و درصد بروتئين در تيمارهاى مختلف

\begin{tabular}{|c|c|c|c|c|c|}
\hline $\begin{array}{c}\text { درصد يروتئين } \\
\text { (cm) }\end{array}$ & درصد روغن & $\begin{array}{c}\text { عملكرد دانه } \\
\text { (kg/ha) }\end{array}$ & $\begin{array}{c}\text { وزن هزاردانه } \\
\text { و (g) }\end{array}$ & $\begin{array}{c}\text { وزن طبق } \\
\text { (g) }\end{array}$ & تيمارها \\
\hline$r_{\circ} / r_{\circ} c$ & $r q / \varphi_{0} c$ & $10 V D / V^{c}$ & $\Lambda r / 94 \mathrm{~b}$ & r d & $T_{1}$ \\
\hline$r \circ / \Delta Y^{b c}$ & M & MTYAd & $\mid Y Y / 94 a$ & r4/940 & $T_{r}$ \\
\hline$r Y / \Delta Y^{a}$ & $r \circ / \wedge \Delta^{b}$ & DQIN/TYc & $\Lambda y^{b b}$ & TG/Trd & $\mathrm{T}_{r}$ \\
\hline$r \mid / 9 q^{4 a}$ & $\Gamma / / \mathcal{e v a b}$ & $\varphi \circ 9 \Delta / \Delta \Delta^{d}$ & Iro/rTa & $9 / / a^{b}$ & $\mathrm{~T}_{\psi}$ \\
\hline$|r| /\left.4\right|^{a b}$ & $\Gamma Y / T \Delta^{a}$ & rara/० qb & lkga & $\mid Y Y / \Lambda^{\mathrm{a}}$ & $\mathrm{T}_{\Delta}$ \\
\hline$r M / \Psi V^{a}$ & $r q / 9 \Lambda^{c}$ & q。rV/Tra & $q r^{b}$ & $a r / V G b$ & $\mathrm{~T}_{4}$ \\
\hline
\end{tabular}

ميانكين هاى داراى حداقل يك حرف مشترى در هر ستون در هر تيمار، تفاوت معنىدارى در سطح احتمال ينج درصد ندارند (LSD).

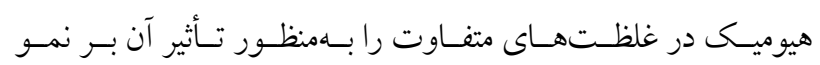

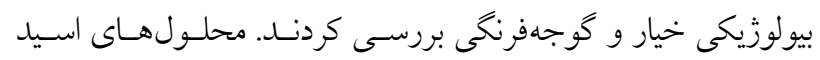

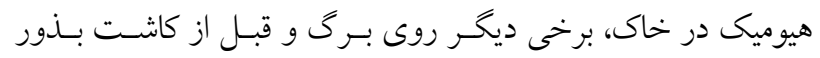

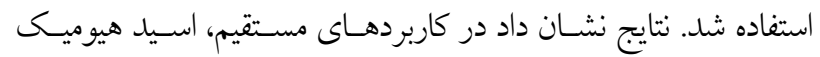

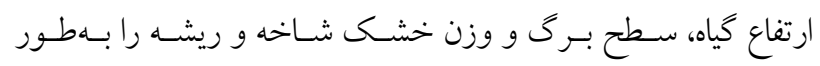

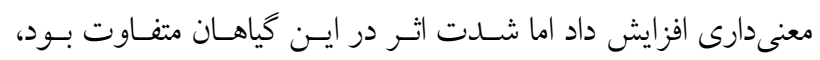
همجينين مقادير بسيار بالا باعث اثرات نامطلوب رشد كيـاهى شـده و

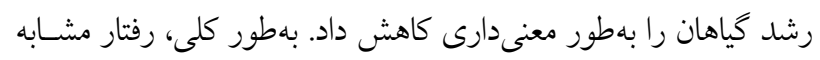
هورمونهاى كَاهى كه به اسيد هيوميك نسبت داده شده تأييد شد.

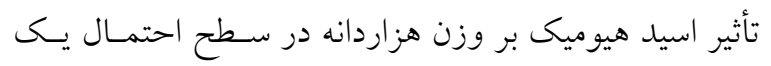

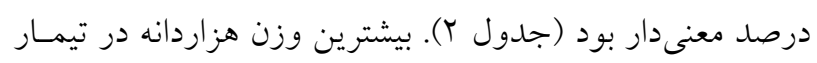

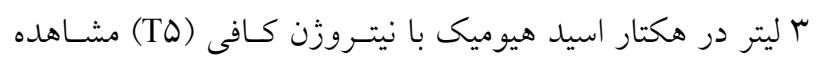

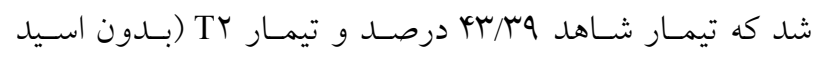

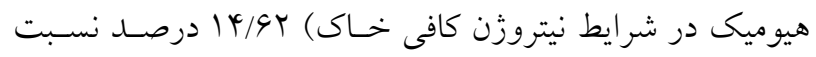

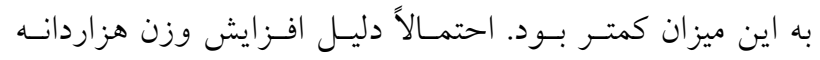

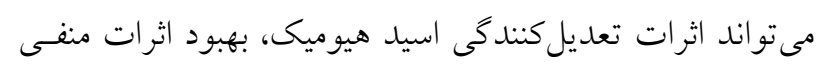

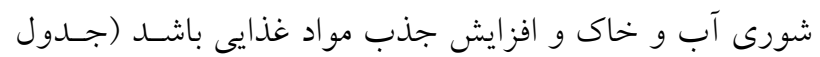
Y). تحقيقات نشان مىدهد تيمار اسيد هيوميكى در خـاكهـاى

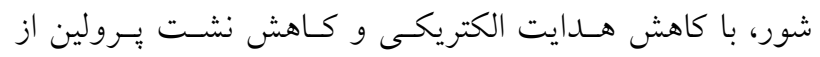

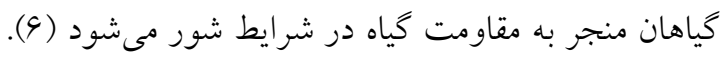

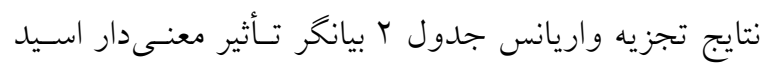
هيوميك در سطح احتمال يك درصد بـر درصــ روغـن اسـت.
رشد رويشى و در بيى آن، وزن خشى كياه افزايش يافتـه اسـت. در برخى مطالعات، مواد هيوميكى تحمل كياهـان در برابـر تــشهــا را افزايش داده و با افزايش جذب مواد غذايى، باعث بهبود رشــ كيـاه شده است (צY). كاربرد اسيد هيوميك موجب افزايش وزن خشكى

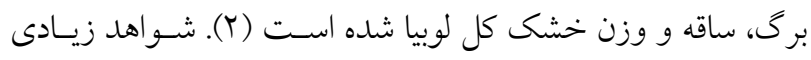
نشان مى دهد كه اسيدهاى فوليـك و هيوميـى مسى توانــــ بـا مـواد

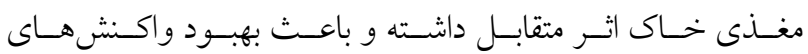

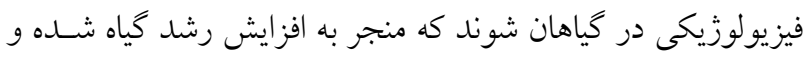

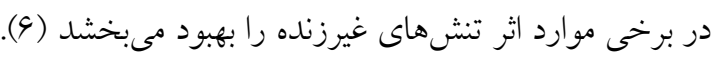

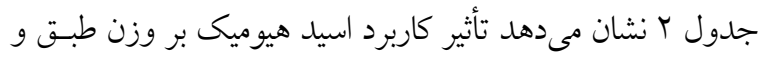
عملكرد دانه در سطح احتمال يك درصــ معنسى دار اسـت. بيشـترين

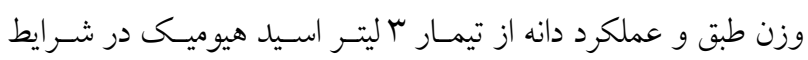

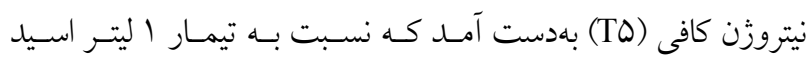

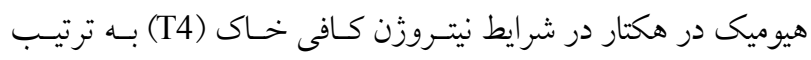

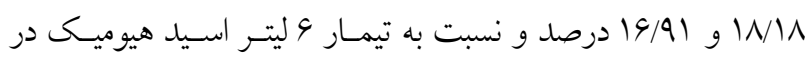

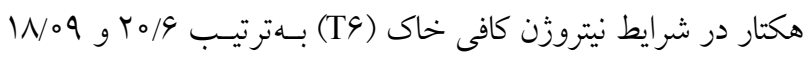

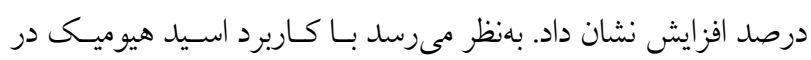

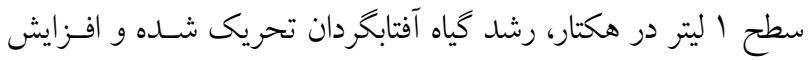

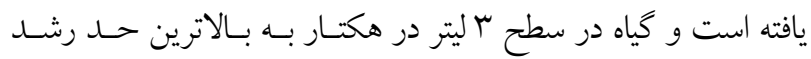

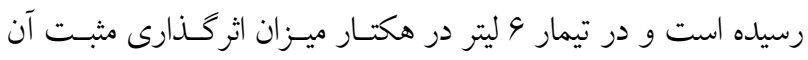

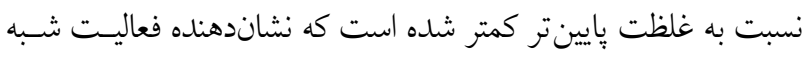

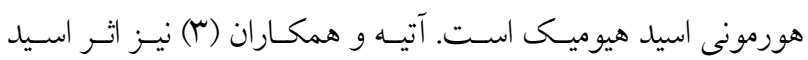


و درصد يروتئين نسبت به شاهد (T) اخستلاف معنسىدار داشـته

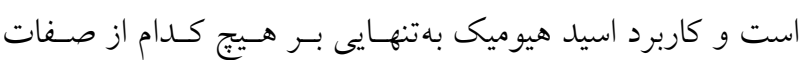

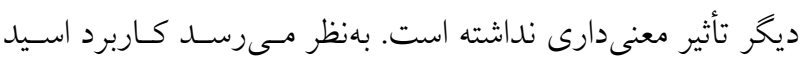

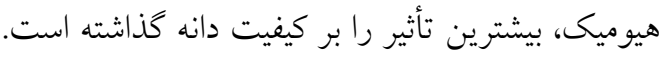

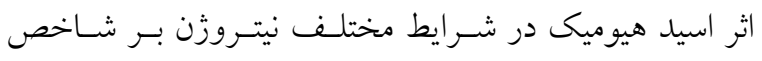
برداشت معنى دار بود (جدول Y). بيشترين شـاخص برداشـت در

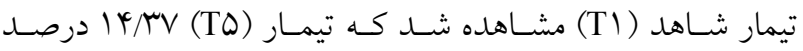
نسبت به اين ميزان كمتر بـود (جــول r). در بررسسى اثـر اسـيد هيوميك بر شاخص برداشت تيمار TD بالاترين شاخص برداشـت

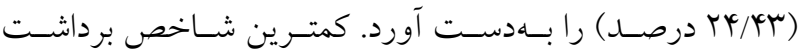

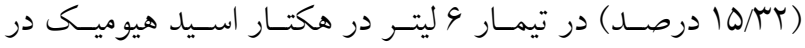

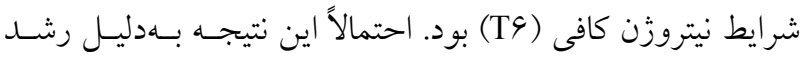
رويشى زياد نسبت به عملكرد دانه بهدست آمده است.

\section{نتيجه گيرى}

با توجه به نتايج بهدست آمده، كـاربرد اسـيد هيوميكى در يـى

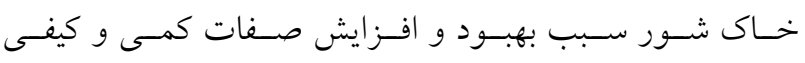

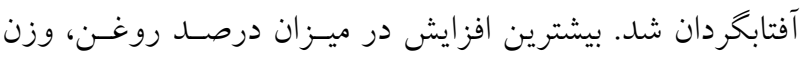

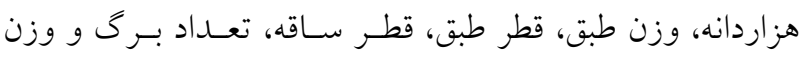
بوته از كاربرد ץ ليتر اسيد هيوميكى در شـرايط كـافى نيتـروزن و و بيشترين افزايش در ارتفاع بوتسه در تيمـار (TQ) اسيد هيوميك در شرايط كافى نيتروزن) و نيـز بيشـترين درصــ يروتئين از اليتر اسيد هيوميـك در هكتـار در شـرايط نيتـروزن

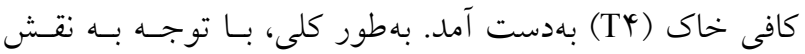
مؤثر اسيد هيوميك در كـاهش اثـرات منفى شـورى و افزايش بهروزى كودهاى شيميايى، استفاده از اين ماده آلى در شـرايط شور خاك و آب بهخصوص در كاربرد بل ليتر اسيد هيوميكى در شرايط كافى نيتروزن قابل توصيه است.

\section{سياسگزارى}

بدين وسيله از حمايتهاى مالى دانشخاه شهركرد در اجراى اين يزووهش تشكر و قدردانى بهعمل مى آيد.
بيشترين درصد روغن مربوط به تيمار ب ليتر اسـيد هيوميـى در

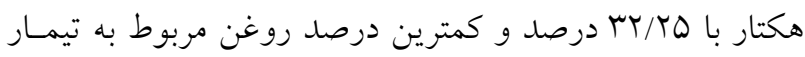

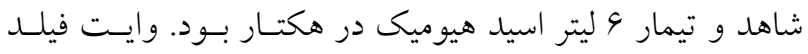

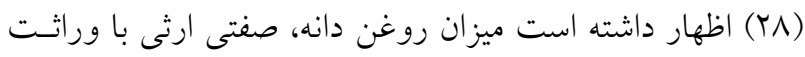
يذّيرى بالا است اما، تا حدودى تحت تأثير محيط قرار مى گيرد.

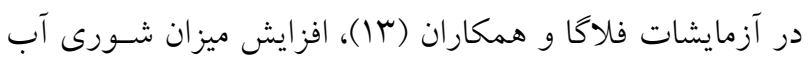

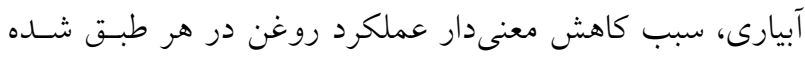

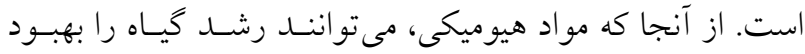

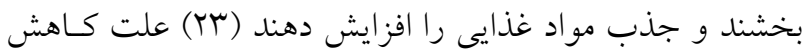
درصد روغن دانه، در تيمار و ليتر در هكتار مسىتوانسد ناشسى از افزايش نيتروزن در دسترس كياه باشد كه باعث كـاهش درصـد روغن و افزايش درصد يروتئين مىشود. بهنظر مىرسـد مقــادير بالاتر نيتروزن، موجب كاهش ميزان روغن دانـه شــه، كـه ايـنـ

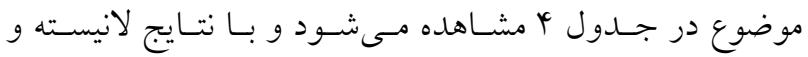
همكاران (1) مطابقت دارد. مـرادى تـلاوت و همكـاران (19) كزارش كردند كه با افـزايش نيتـروزن در كلـزا، درصــ روغـن كاهش و درصد يروتئين افزايش مى يابد.

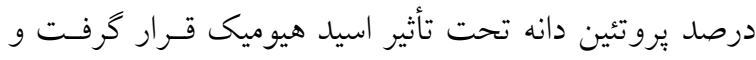
در سطح احتمال بينج درصد معنى دار شد. بيشترين درصد بروتئين

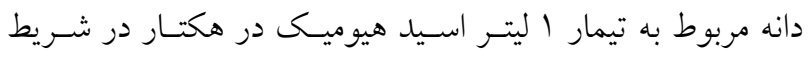

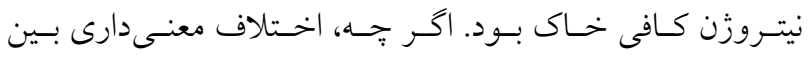

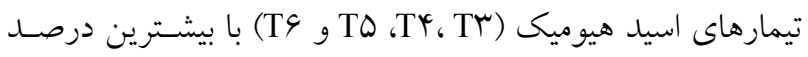
يروتئين و بقيه تيمارها با مقادير كمتر هـروتئين مشـاهده شـــ امـا

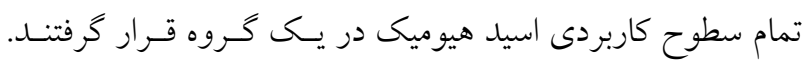

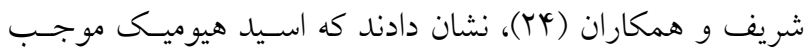

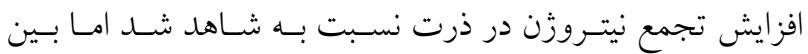
سطوح مختلف اسيد هيوميك تفاوت معنىدارى وجـود نداشـت.

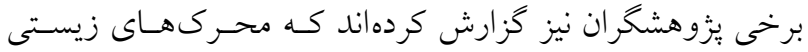

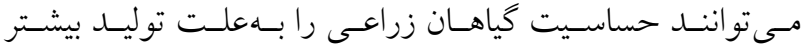

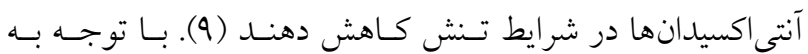
جدولهاى ب و با تيمار ب ليتر اسيد هيوميك در هكتار در شـرايط ناكافى نيتروزن خاك، تنها در سه صفت قطر ساقه، درصد روغـن 
1. Assouline, S., M. Moller, S. Cohen, M. Ben-Hur, A. Grava, K. Narkis and A. Silber. 2006. Soil-plant system response to pulsed drip irrigation and salinity: bell pepper case study. Soil Science Society of America Journal 70: 1556-1568.

2. Astaraei, A. R. 2008. Effect of organic sources as foliar spray and root media on nutrition in cowpea plant. American-Eurasian Journal of Agricultural and Environmental Sciences 3: 352-356.

3. Atiyeh, R. M., S. Lee, C. A. Edwards, N. Q. Arancon, J. D. Metzger. 2002. The influence of humic acids derived from earthworm-processed organic wastes on plant growth. Bioresource Technology 84: 7-14.

4. Ayas, H. and F. Gulser. 2005. The effect of sulfur and humic acid on yield components and macronutrient contents of spinach. Biological Sciences 5(6): 801-804.

5. Bot, A. J., F. O. Nachtergaele and A. Young. 2000. Land resource potential and constraints at regional and country levels. In: World soil resources reports (FAO), no. 90/FAO, Rome (Italy). Land and Water Development Division.

6. Calvo, P., L. Nelson and J. W. Kloepper. 2014. Agricultural uses of plant biostimulants. Plant and Soil 3-41.

7. Canellas, L. P., D. M. Balmori, L. O. Medici, N. O. Aguiar, E. Campostrini, R. C. C. Rosa, A. R. Facanha and F. L. Olivares. 2013. A combination of humic substances and Herbaspirillum seropedicae inoculation enhances the growth of maize (Zea mays L.). Journal Plant and Soil 366: 119-132.

8. Caterina, R. D., M. M. Giuliani, T. Rotunno, A. D. Caro and Z. Flagella. 2007. Influence of salt stress on seed yield and oil quality of two sunflower hybrids. Annals of Applied Biology 151(2): 145-154.

9. Ertani, A., O. Francioso, V. Tugnoli, V. Righi and S. Nardi. 2011. Effect of commercial lignosulfonate-humate on Zea mays L. metabolism. Journal of Agricultural and Food Chemistry 59: 11940-11948.

10. Eyheraguibel, B., J. Silvestre and P. Morard. 2008. Effects of humic substances derived from organic waste enhancement on the growth and mineral nutrition of maize. Bioresource Technology 99(10): 4206-4212.

11.FAO. 2002. The salt of the earth: hazardous for food production. http://www.fao.org/worldfoodsummit/english/newsroom/focus/ focus1.htm. Last accessed February 2015

12. FAO. 2009. Advances in the assessment and monitoring of salinization and status of biosaline agriculture. Reports of expert consultation held in Dubai, United Arab Emirates, 26-29 November 2007. World Soil Resources Reports No. 104. FAO, Rome.

13. Flagella, Z., M. M. Giuliani, T. Rotunno, R. Dicaterina and A. Decaro. 2004. Effect of saline water on oil yield and quality of a high oleic sunflower hybrid. European Journal of Agronomy 21: 267-272.

14. Jiang, J., Z. Huo, S. Feng and C. Zhang. 2012. Effect of irrigation amount and water salinity on water consumption and water productivity of spring wheat in Northwest China. Field Crops Research 137: 78-88.

15. Kaya, Y., S. Jocic and D. Miladinovic. 2012. Sunflower. PP. 85-129. In: Gupta, S. K. (Eds.), Technological Innovations in Major World Oil Crops, Volume 1. Springer.

16. Khatoon, A., M. K. Hussain and M. Sadiq. 2000. Effect of salinity on some growth parameters of cultivated sunflower under saline conditions. International Journal of Agriculture and Biology 2(4): 210-213

17. Kjeldahl, J. 1883. A new method for the determination of nitrogen in organic matter. Zeitschreft fur Analytische Chemie 22: 366-1883.

18. Laaniste, P., J. Joudu and V. Eremeev. 2004. Oil content of spring oilseed rape seeds according to fertilization. Agronomy Research 2(1): 83-86.

19. Moradi Telavat, M. R., S. A. Siadat, H. Nadian and G. Fathi. 2007. Response of canola grain and oil yields, oil and protein contents to different levels of nitrogen and boron fertilizers in Ahwaz region. Iranian Journal of Crop Sciences 9(3): 213-224. (In Farsi).

20. Nardi, S., D. Pizzeghello, A. Muscolo and A. Vianello 2002. Physiological effects of humic substances on higher plants. Soil Biology and Biochemistry 34: 1527-1536.

21. Nobre, R. G., H. R. Gheyi, F. A. L. Soares and J. A. F. Cardoso. 2011. Sunflower production under saline stress and nitrogen fertilization. Journal of Revista Brasilia. 35: 929-937.

22. Rose, M. T., A. F. Patti, K. R. Little, A. L. Brown, W. R. Jackson and T. R. Cavagnaro. 2014. Chapter two-A MetaAnalysis and Review of Plant-Growth Response to Humic Substances: Practical Implications for Agriculture. Sparkers D. L. Advances in Agronomy. Department of Plant and Soil Sciences. University of Delaware. Newark. USA. pp. 37-89.

23. Sangeetha, M., P. Singaram, and R. D. Devi. 2006. Effect of lignite humic acid and fertilizers on the yield of onion and nutrient availability. Paper Presented at the 18th World Congress of Soil Science, July 9-15, Philadelphia, Pennsylvania.

24. Sharif, M., R. A. Khattak, and M. S. Sarir. 2002. Effect of different levels of lignitic coal derived humic acid on growth of maize plants. Communications in Soil Science and Plant Analysis 33: 3567-3580.

25. Soxhlet, F. 1879. Die gewichtsanalytische Bestimmung des Milchfettes. Dingler's Polytechnisches Journal 232: pp. 
مقاله علمى - بروهشى: تأثير اسيد هيوميك بر شاخصهاى رشد و عملكرد....

461-465. (in German).

26. Tan, K. H. 2003. Humic Matter in Soil and Environment: Principles and Controversies. New York: Marcel Dekker.

27. Travassos, K. D., F. A. L. Soares, H. R. Gheyi, D. R. S. Silva and A. K. Nascimento. 2011. Achene production of the sunflower irrigated with brackish water. Revista Brasileira 15: 371-376.

28. Whitfield, D. M. 1992. Effects of temperature and ageing on $\mathrm{CO}_{2}$ exchange of pods of oilseed rape (Brassica napus). Field Crop Research 28: 271-280.

29. Winter, S. and K. Ravi. 2003. Sunflower. PP. 755-771. In: Loebenstein, G. and G. Thottappilly (Eds.), Virus and Virus-like Diseases of Major Crops in Developing Countries. Springer. 


\title{
Effect of Humic Acid on Growth and Yield Indices of Sunflower (Helianthus annuus) in a Saline Soil
}

\author{
M. R. Tadayon ${ }^{1 *}$, A. Tadayon ${ }^{2}$ and S. Esmaili ${ }^{3}$
}

(Received: January 23-2016; Accepted: April 11-2021)

\begin{abstract}
This field experiment was carried out in order to investigate the effects of humic acid on the growth and yield of sunflower in a saline soil, using a complete block design with three replications in Kashan, central Iran, in 2014. Treatments consisted of 3 levels of humic acid (1, 3 and 6 liters per ha), no humic acid in soil with sufficient nitrogen, three liters of humic acid per ha in soil without sufficient nitrogen, control of humic acid in soil without sufficient nitrogen. The results showed that the use of humic acid left significant effect on all measured traits. The greatest increase in oil content, 1000 seed weight, head weight, seed yield, head diameter, stem diameter and number of leaves were obtained by use of 3 liters of humic acid in soil with sufficient nitrogen. Maximum increase in plant height and plant weight were obtained by using 6 liters humic acid in soil with sufficient nitrogen and the highest protein content was achieved by using 1 liter of humic acid per ha in soil with adequate nitrogen. The results of this experiment showed that the application of humic acid in a saline soil improves the growth and yield of sunflower plants.
\end{abstract}

Keywords: Oil seed, electrical conductivity, soil nitrogen, hormones, saline soil

1, 2, 3. Professor, Associate Professor and MSc. Student, Respectively, Department of Agronomy and Plant Breeding, Faculty of Agriculture, Shahrekord University, Shahrekord, Iran.

*: Corresponding Author, Email: mrtadayon@yahoo.com 